\title{
АРХЕОЛОГИЯ
}

УДК 902.2(571.150)

ББК 63.48(2Рос-4Алт)

\section{История открытия и начальные этапы изучения Фирсовского археологического микрорайона}

\author{
А.Л. Кунгуров ${ }^{1}$ О.Ф. Кунгурова \\ ${ }^{1}$ Алтайский государственный университет (Барнаул, Россия) \\ ${ }^{2}$ Финансовый университет при правительстве Российской Федерации, \\ Алтайский филиал (Барнаул, Россия)
}

\section{History of Discovery and Study of the Firsovsky Archaeological Microdistrict}

\author{
A.L. Kungurov ${ }^{1}$, O.F. Kungurova ${ }^{2}$ \\ ${ }^{1}$ Altai State University (Barnaul, Russia) \\ ${ }^{2}$ Finance University under the Government of the Russian Federation, Barnaul \\ Branch (Barnaul, Russia)
}

\begin{abstract}
Фирсовский археологический микрорайон (ФАМ), впервые выделенный и обоснованный А.Б. Шамшиным, является одним из интереснейших археологических комплексов Верхнего Приобья. На относительно ограниченной территории правобережья Оби в устьевой зоне р. Лосихи сосредоточено свыше трех десятков разнофациальных и разновременных объектов. Большое количество археологических объектов на ограниченном отрезке берега можно объяснить несколькими факторами. Первый - это степной характер правого борта долины Оби от села Кислухи до села Фирсово. Такой ландшафт пригоден для эффективного скотоводческого хозяйства. Второй фактор - впадение на этой территории в Обь нескольких малых рек - Лосихи, Повалихи, Кислухи и др. Третий фактор - чрезвычайно богатые биологическими ресурсами территории данного географического региона: обширная речная пойма, сосновый бор и примыкающие к нему степные пространства. Такие памятники, как некрополь Фирсово XIV и поселение позднего бронзового века Фирсово XVIII, являются крупнейшими на юге Западной Сибири. До сих пор при обследовании отдельных участков ФАМ ученые открывают все новые и новые памятники различных эпох. История открытия и изучения данного комплекca, насчитывающая уже более ста лет, является своеобразным срезом, маркирующим различные периоды развития науки, а также создание периодизации и хронологии древнейшей истории региона.
\end{abstract}

Firsovsky Archaeological Microdistrict (FAM), first marked out and grounded by A.B. Shamshin is one of the most interesting archaeological complexes of the Upper Ob. On a relatively limited territory of the right bank of the $\mathrm{Ob}$ in the estuary zone of the Losiha river, more than three dozen differentfacies and different-time objects are concentrated. The large number of archaeological sites on a limited stretch of coast can be explained by several factors. The first is the steppe nature of the starboard side of the Ob valley from the village of Kisluha to the village of Firsovo. This landscape is suitable for an effective pastoral farm. The second factor is the flow of several small rivers in the $\mathrm{Ob}$ - Losiha, Povaliha, Kisluha and others. The third f-actor is the extremely biologically rich territory of this geographical region: extensive river floodplain, pine forest and adjacent steppe spaces. Such monuments as the necropolis of the Firsovo-14 and the settlement of the late Bronze Age the Firsovo-18 are the largest ones in the south of Western Siberia. And still, up to now, when examining individual sections of the FAM, scholars discover more and more monuments of different eras. The history of the discovery and study of this complex, numbering more than 100 years, is a kind of slice marking the different periods of science development, as well as the formation of periodization and chronology of the region's most ancient history. 
Ключевые слова: история, коллекции, эпоха, период, культура, керамика, некрополь, поселение.

DOI 10.14258/izvasu(2019)6-17

Фирсовский археологический микрорайон (ФАМ) расположен на юго-западной оконечности БийскоЧумышской возвышенности, граничащей с северо-восточным бортом долины Оби. Этот район пересекает ряд рек - правых притоков Оби, крупнейшей из которых является Лосиха (длина водотока 150 км), выходящая в долину Оби около с. Фирсово. Остепненный берег образует борт, организованный в систему мысов и террасовых уступов высотой до 145 м над у.м. (до 16 м над уровнем поймы и 20 м над урезом воды). Некоторые участки поднимаются от уровня поймы очень полого. На мысу, имеющем название Березовый, на участках высокой поймы, примыкающих к пологим кромкам борта долины, расположены несколько крупных андроновских поселений, наиболее известное из которых Фирсово XV [1, с. 70; 2, с. 350].

По физико-географическому районированию ФАМ входит в Повалихинский район Заобской правобережной подпровинции Верхнеобской провинции Западно-Сибирской страны [3, с. 151]. В данном регионе смыкаются три крупных ландшафтных района: пойма Оби, остепненное правобережье и Приобский боровой массив. Пойма Оби имеет низменный недренированный (гидроморфный) луговой ландшафт с пойменными супесчано-суглинистыми низкими террасами. Распространены разнотравнозлаковые и осоково-злаковые луга на болотно-луговых аллювиальных почвах, старичные понижения, эрозионно-дифляционные котловины с осоковыми, вейниковыми и тростниковыми болотами. Обычны старичные озера и протоки. Некоторые болота имеют названия (урочище Подвалешня, Утопша). Пойменная зона Оби чрезвычайно богата разнообразными биоресурсами.

Особенностью географических условий ФАМ является выход к пойме на протяжении свыше 30 км остепненной зоны (от окрестностей пос. Белоярска до с. Фирсово). Она имеет низменный дренированный (неоэлювиальный) лугово-степной ландшафт. На данном участке правобережья распространены плосковолнистые лессовые террасы со злаковоразнотравными степями в сочетании с березовыми и осиново-березовыми травяными колками. Северозападнее Белоярска и юго-восточнее Фирсова начинаются сосновые и березово-сосновые травяные кустарниковые леса на дюнно-грядовых перевеянных песчаных террасах. Степные участки сохраняются только на кромках террас, примыкающих к пойме Оби, и останцах коренного берега, имеющих местное наименование «елбаны».
Key words: history, collections, era, period, culture, ceramics, necropolis, settlement.
Сосредоточение разнообразных памятников в окрестностях Фирсова связано с комплексом благоприятных географических условий:

1) устьевая зона Лосихи;

2) обширная обская пойма, изобилующая различными биоресурсами и пригодными для выпаса скота заливными лугами;

3) близость соснового Приобского бора, позволяющего вести интенсивный охотничий промысел и заготовку древесины;

4) наличие удобных для организации поселений и могильников остепненных мысов и террас;

5) относительная природная защищенность и скрытность местности и вместе с тем доступность благодаря выработанным речным долинам, русла Оби и степным пространствам Обь-Чумышского водораздела.

Начальный этап изучения (с 20-х до середины 70-х гг. XX в.). Первые археологические находки на территории Первомайского района связаны с именем Михаила Диановича Копытова (1869 - после 1932), краеведа, одного из основателей Бийского краеведческого музея. К сожалению, точное расположение и характер открытых им памятников неизвестен, так как многие материалы начала XX в. или утеряны, или потеряли адресность в ходе бурных событий Гражданской войны и установления советской власти на Алтае. В архиве Бийского краеведческого музея (БКМ. ДО. Ф. 1. Д. 3) хранится сводка памятников Алтайского края, составленная М.Д. Копытовым, где в Списке поселений и могильников бронзового века указана Бобровка, а в Списке поселений и стоянок первобытного человека, находящихся в селах Бийского и Барнаульского уезда и расположенных в области распространения древних речных аллювиальных отложений, отмечены Рассказиха и Фирсово $[4$, c. 278]. В последний список краевед включал памятники, датирующиеся, по его представлениям, каменным веком, а значит, представленные находками более-менее выразительных каменных орудий. В настоящее время в окрестностях этих сел известны памятники с каменными изделиями различного времени (преимущественно неолитическими), однако локализовать их на местности по столь скудным данным невозможно. Сведений о возможности посещения археологических объектов, открытых М.Д. Копытовым, его коллегами и преемниками С.М. Сергеевым (1879-1947) и А.П. Марковым (1904-1976) не сохранилось, но исключать этого нельзя, так как после приезда на Алтай Сергей 
Михайлович Сергеев не только ознакомился с материалами фондов Бийского музея, но и совместно с Михаилом Диановичем посетил все известные памятники. Вполне возможно и посещение окрестностей Фирсова А.Д. Сергеевым (1931-2002), который работал учителем в школах Повалихи (1953-1955) и Бобровки (1955-1958), а затем директором Алтайской краевой станции юных туристов. Именно в этот период им были открыты и частично исследованы поселение Мыльниково и могильник раннего железного века Обские Плесы 2. Однако достоверных сведений о деятельности краеведа в этом районе не сохранилось [2, с. 328].

Второй этап изучения (середина 1970-х - середина 1980-х гг.). Начало профессионального исследования памятников археологии ФАМ связано прежде всего с работами сотрудника Института археологии АН СССР Владислава Александровича Могильникова (1932-2002). В 1974-1975 гг. он исследовал курганы монгольского времени на могильнике Кармацкий [5, с. 92] и аварийный грунтовый некрополь Новоалтайский [6, с. 63], расположенный в месте современного поворота с трассы Новосибирск - Барнаул на новый объездной мост через Обь.

В работах В.А. Могильникова 1975 г. в Первомайском районе принимали участие тогда еще школьники Артур Леонидович Кунгуров и Вадим Борисович Бородаев. Позднее, во второй половине 70-х гг., уже будучи студентами, они регулярно проводили осмотр берегового участка между станцией Развилка и с. Бобровка, проводя своеобразный мониторинг разрушений антропогенного и природного характера и открывая новые археологические памятники. Осенью 1975 г. ими было найдено Новоалтайское поселение [2, с. 344-345; 7, с. 70]. Позднее в этом же году А.Л. Кунгуров и С.Ю. Гусев осмотрели кромку берега перед с. Фирсово. Надо отметить, что она имела существенно иной, чем сейчас, вид. За мысом с Новоалтайским поселением располагался крупный песчаный карьер. Далее кромка берега была распахана почти под абрис, вдоль которого проходила грунтовая дорога и располагались глубокие песчаные раздувы. В котлованах разрушений были собраны артефакты, маркирующие известные сейчас памятники Фирсово I-XI [2, с. 346-348]. При этом на объекте Фирсово XI в 1975 г. были подобраны пастовые бусы и бисер, кости человека и несколько каменных изделий неолитического облика. Раздувы жители Фирсово пытались остановить тополево-ветловыми лесополосами, при организации которых песчаная поверхность бороздилась глубокими траншеями. Пока саженцы не принялись, антропогенные повреждения поверхности активно раздувались, обнажая значительное количество артефактов.
Таким образом, первую точную фиксацию памятников ФАМ можно отнести к 1975 г. Осенью 1977 г. А.Л. Кунгуровым была сделана первая находка на некрополе, получившем в дальнейшем наименование Фирсово XIV. Это был черешковый бронзовый кинжал. Несмотря на раскопки нескольких аварийных могил на Новоалтайском поселении и Подвалешне [2, с. 345], крупные исследовательские работы в ФАМ до середины 1980-х гг. не проводились.

третий этап изучения. Активные работы в Первомайском районе, связанные с исследованием археологических памятников, начались с образованием в Алтайском государственном университете сначала хоздоговорной Лаборатории археологии (1978 г.), а затем Музея археологии и этнографии Алтая (1985), кафедры археологии, этнографии и источниковедения (1988) и Научно-исследовательского института гуманитарных исследований (1989).

В конце 1970-х гг. все открытые ранее памятники были картографированы и включены в Отчеты по Открытым листам ИА АН СССР. Таким образом, предварительные наименования и нумерация памятников стали вполне официальными. В 1978 г. В.Б. Бородаевым и А.Л. Кунгуровым также были исследованы первые разрушающиеся погребения некрополя Фирсово XIV - безынвентарное детское погребение на южной оконечности комплекса в небольшом карьере и захоронение отдельного черепа человека с размещенным рядом ирменским сосудом, стоящим «вверх дном», в центральной части.

С середины 1984 г. исследования Фирсовского археологического микрорайона начал Александр Борисович Шамшин (1956-2018). Под его руководством осуществлялись прежде всего раскопки поселения позднего бронзового века. Именно А.Б. Шамшин и обосновал особенности данного археологического микрорайона и присвоил ему наименование «Фирсовский» $[8$, с. 331; 9; 10]. Тогда же при осмотре правого берега Лосихи А.Л. Кунгуровым и М.Т. Абдулганеевым (1958-2009) были открыты крупное поселение позднего бронзового века Фирсово XVIII, поселение кулайской культуры Булочка [2, с. 352], расположенное на останце, и мысовые городища Усть-Лосиха 1 и 2, относящиеся к одинцовской культуре [11, с. 14].

Начало раскопок некрополей и поселений ФАМ началось в1988 г. в связи с планированием строительства нового моста через Обь. Никаких предварительных обследований не проводилось, археологи не были ознакомлены даже с планами строительства. Однако во время очередного мониторинга состояния объектов ФАМ исследователи неожиданно зафиксировали активные строительные работы, в процессе которых часть памятников уже была разрушена. А.Л. Кунгуров обратился в ГРТК «Алтай» с предложением сделать репортаж о происходящих событиях. 
В то время в телевизионном эфире Алтайского края существовала популярная программа «Пятница», руководство которой осуществлял известный в крае телевизионный и радиожурналист Ю.В. Масалов (1948-2012). Им был снят сюжет о разрушении археологических памятников, оперативно показанный в программе «Пятница». Однако еще до выхода в эфир данного материала руководство строительства моста, узнавшее о проведенных съемках, обра- тилось в Алтайский государственный университет с предложением заключения хоздоговора на исследование аварийных объектов.

Исследования памятников, как попадающих в зону разрушения при строительстве дорог и развязок, так и разрушающихся по другим причинам, продолжается до настоящего времени, однако это уже материал для дальнейших исследований [12, с. 4-5].

\section{Библиографический список}

1. Кунгуров А.Л. Работы Бийского отряда // Исследования памятников древних культур Сибири и Дальнего Востока. Новосибирск:, 1987.

2. Кунгуров А.Л. Памятники археологии Первомайского района // Сохранение и изучение культурного наследия Алтайского края. Вып. XV. Барнаул, 2006.

3. Алтайский край : атлас. Т. 1. Москва ; Барнаул, 1978.

4. Кунгуров А.Л. Научная деятельность М.Д. Копытова // Алтайский сборник. Вып. XVI. Барнаул, 1995.

5. Могильников В.А. Исследование Кармацких курганов // Проблемы сохранения, использования и изучения памятников археологии. Горно-Алтайск, 1992.

6. Фролов Я.В. Материалы скифского времени из Новоалтайского могильника // Современные проблемы археологии России. Т. ІІ. Новосибирск, 2006.

7. Шамшин А.Б. Новоалтайское поселение // Алтайский сборник. Вып. XVII. Барнаул, 1993.

8. Шамшин А.Б. Фирсовский археологический микрорайон. Некоторые итоги и перспективы исследования //
Проблемы археологии, этнографии, антропологии Сибири и сопредельных территорий. Т. III. Новосибирск, 1997.

9. Позднякова О.А. Проблема интерпретации погребений женщин с головными уборами (по материалам андроновского комплекса могильника Фирсово XIV) // Наследие древних и традиционных культур Северной и Центральной Азии. Т. III. Новосибирск, 2000.

10. Нехведавичюс Г.Л., Ведянин С.Д. Музей археологии Алтайского государственного университета // Алтайский сборник. Вып. ХУ1. Барнаул, 1995.

11. Казаков А.А. Одинцовская культура БарнаульскоБийского Приобья. Барнаул, 2014.

12. Кирюшин Ю.Ф., Папин Д.В., Тур С.С., Пилипенко А.С., Федорук А.С., Федорук О.А., Фролов Я.В. Погребальный обряд древнего населения Барнаульского Приобья (материалы из раскопок 2010-2011 гг. грунтового могильника Фирсово-XIV). Барнаул, 2015. 